\title{
Twenty Years of Changes in Grass Production Following Mesquite Control and Reseeding
}

\author{
DWIGHT R. CABLE
}

Highlight: Production of native perennial grasses and seeded Lehmann lovegrass was measured periodically for 21 years on a semidesert area where velvet mesquite was controlled by 2,4,5-T aerial spray and on an adjacent unsprayed area to determine how mesquite control would affect grass production and how long the effect would last. Grass production on the sprayed area increased dramatically during the first 5 years in a time-dependent relationship in response to the higher levels of available soil moisture. During the last 12 years, changes in lovegrass production were associated with changes in summer rainfall of the current and previous summers and of the intervening winter (2 separate variables). Because of the strong competition from lovegrass, native grass production during the last 12 years did not show its usual relationship with summer rainfall, but decreased gradually and consistently on both the sprayed and unsprayed areas. At the end of the study period, native grasses provided only $10 \%$ of the total perennial grass production on the sprayed area and $20 \%$ on the unsprayed. Increased grass production, resulting from the mesquite control treatment and seeding, paid for the treatment within 4 years, and the sprayed area was still producing more grass than the unsprayed area 20 years later.

Forage production can be increased on semidesert range by killing velvet mesquite (Prosopis juliflora var. velutina) and seeding grass. However, before committing his resources, a rancher or land manager needs answers to such questions as: How much will forage production increase? How long will the increase last? How soon must the job be done again? Records of vegetation changes for 20 years after spraying and seeding on the Santa Rita Experimental Range in southern Arizona (Fig. 1) have provided some answers to these questions.

\section{Methods}

The mesquite was sprayed with 2,4,5-T by airplane in May 1954 and again in June 1955 on 100 acres of mesquitedominated semidesert rangeland at an elevation of about 3,800 ft (mesquite density about 225 trees/acre). The aerial spray treatments consisted of applying $1 / 2$ or $3 / 4 \mathrm{lb} /$ acre acid equivalent of 2,4,5-T in a 1:4 diesel oil-water emulsion at the rate of 5 gallons per acre.

Author is principal range scientist, Rocky Mountain Forest and Range Experiment Station, Tucson, Arizona, with the Forest Service, U.S. Department of Agriculture, which has central headquarters at Fort Collins in cooperation with Colorado State University. Author is located at Tucson in cooperation with the University of Arizona.

Manuscript received October 1, 1975.
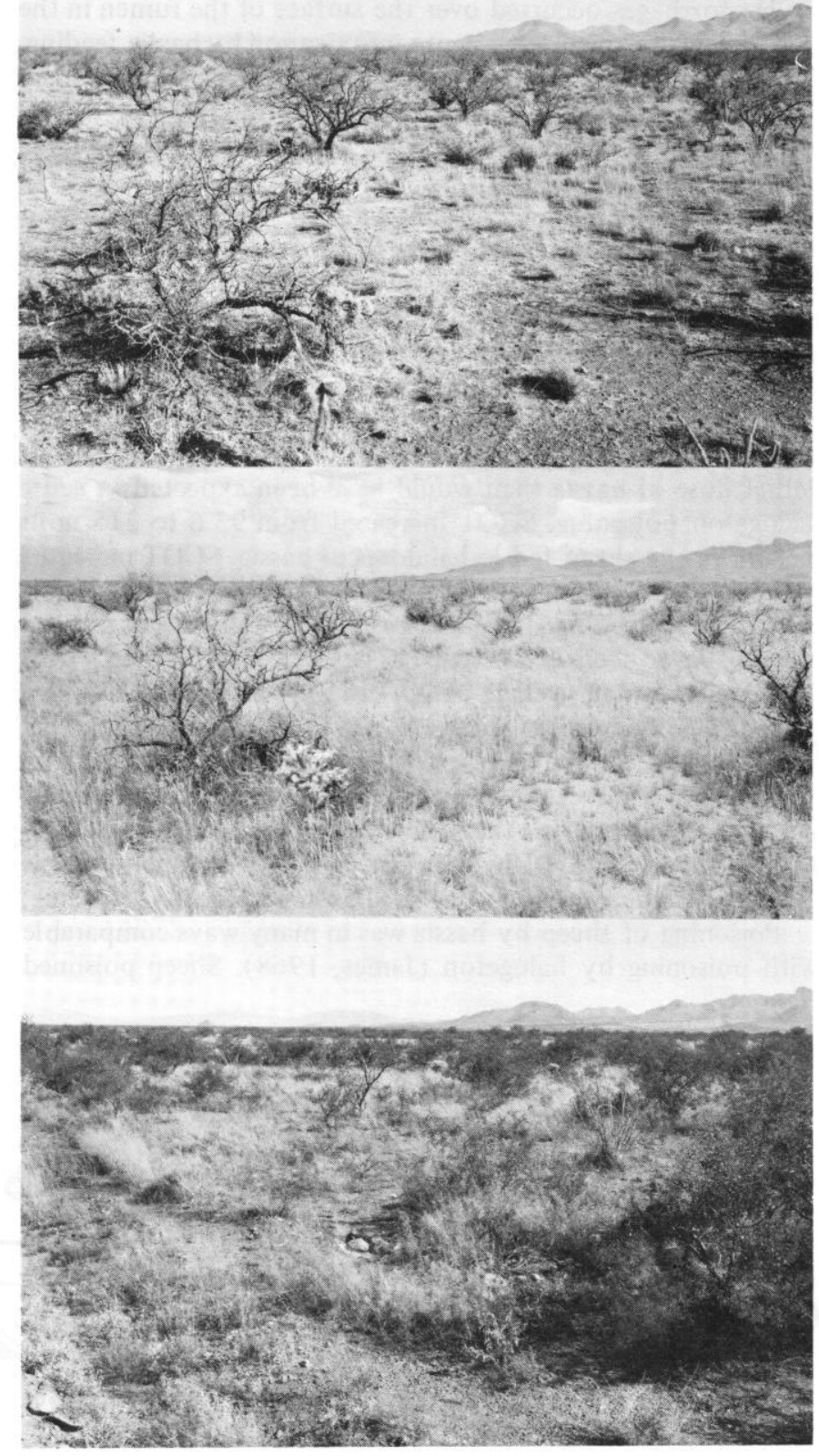

Fig. 1. Sprayed area: (upper) December 1956, 3 growing seasons after initial mesquite control treatment; (middle) September 1958, year of highest grass herbage production; (lower) October 1974, showing considerable mesquite recovery. 
At the time of the first spraying, Lehmann lovegrass (Eragrostis lehmanniana) was aerially seeded without seedbed preparation at $1 \mathrm{lb} /$ acre on the 100 -acre sprayed area and also on a similar adjacent unsprayed area. Herbage production of annual and perennial grasses, by species, was measured annually in the fall from 1954 to 1959 , and periodically thereafter, until 1974.

Principal native species present were Arizona cottontop (Trichachne californica), plains bristlegrass (Setaria macrostachya), sideoats grama (Bouteloua curtipendula), and perennial three awn (A ristida spp.).

\section{Results and Discussion}

The reduction of mesquite on the sprayed area, and the establishment of lovegrass on the sprayed and unsprayed areas set in motion the broad trends in vegetation change during the 21-year study period. The broad trends consisted of increases in both native grasses and lovegrass in the early years, followed by a continuing gradual replacement of native grasses by lovegrass during the latter part of the pcriod. Production of lovegrass responded strongly to changes in seasonal rainfall during the latter part of the study, but the usual rainfallproduction relationship for native perennial grasses was suppressed by competition from lovegrass.



Fig. 2. Precipitation for June through August and September through May for the 21-year study period. $(\mathrm{X}=$ years in which herbage production was measured.)

\section{Seasonal Rainfall}

Winter precipitation (September-May), averaged low for the first 8 years and the last 6 years, about half as much as during the middle 7 years (Fig. 2). Summer rainfall (June-August), on the other hand, was unusually high during the first 6 years of the study, but averaged $40 \%$ less during the last 15 years (Fig. 2 ). These differences in seasonal rainfall are important because the native grasses and lovegrass differ in their growth patterns and respond differently to seasonal rainfall.

\section{Mesquite Control}

The mesquite control treatments killed about half of the trees and reduced mesquite crown cover about 90\% (Fig. 1 upper). The mesquite stand recovered very slowly, and by 1974 the mesquite density was 216 trees/acre compared to 225 before control (Fig. 1 lower). However, since nearly half of these trees were less than 20 years old in 1974, the competitive impact of mesquite on grass production was still much less in 1974 than before control. The mesquite stand on the unsprayed area probably changed very little during the study period. On an adjacent 1,000-acre pasture, mesquite density changed only from 173 trees/acre to 175 trees/acre during the 10-year period 1957-66.

\section{Grass Production}

Grass herbage production was affected by differences in competitiveness between lovegrass, native grasses, and mesquite, as well as by changes in rainfall. Normally the native grass stand is in equilibrium with the mesquite, and grass herbage production varies predictably with rainfall. On the Santa Rita, for example, changes in rainfall for June September of the previous year and rainfall for the current August together account for from 64 to $91 \%$ of the year-toyear changes in native perennial grass production (Cable, 1975).

On the study area, this rainfall-production equilibrium was disturbed by: (1) controlling mesquite on part of the area, (2) seeding the lovegrass, and (3) unusual rainfall. Changes in grass production after spraying and seeding reflect the readjustments among native grasses, lovegrass, and mesquite as they established new equilibriums on the sprayed and unsprayed areas.

The native grasses and lovegrass reacted differently to the changed competitive situation because of inherent differences in competitiveness, and in relative dependence on summer and winter precipitation. Native grasses are less competitive than lovegrass; and native grass production depends largely on summer rainfall, whereas lovegrass is more competitive and yields depend about equally on summer and winter precipitation. These differences in growth characteristics together with the seasonal rainfall changes (Fig. 2) help explain changes in grass production during the study period.

\section{Native Grass Production}

Herbage production of native grasses on the sprayed area increased dramatically during the first 2 years (Fig. 3). This response was the result of two successive years of higher summer rainfall coupled with the near-elimination of mesquite competition. During the first 5 years, summer rainfall was relatively high, and changes in native grass production were affected about equally by: (1) time-as grasses increased to make use of soil moisture made available by killing the mesquite, and (2) summer rainfall-as expressed by the 


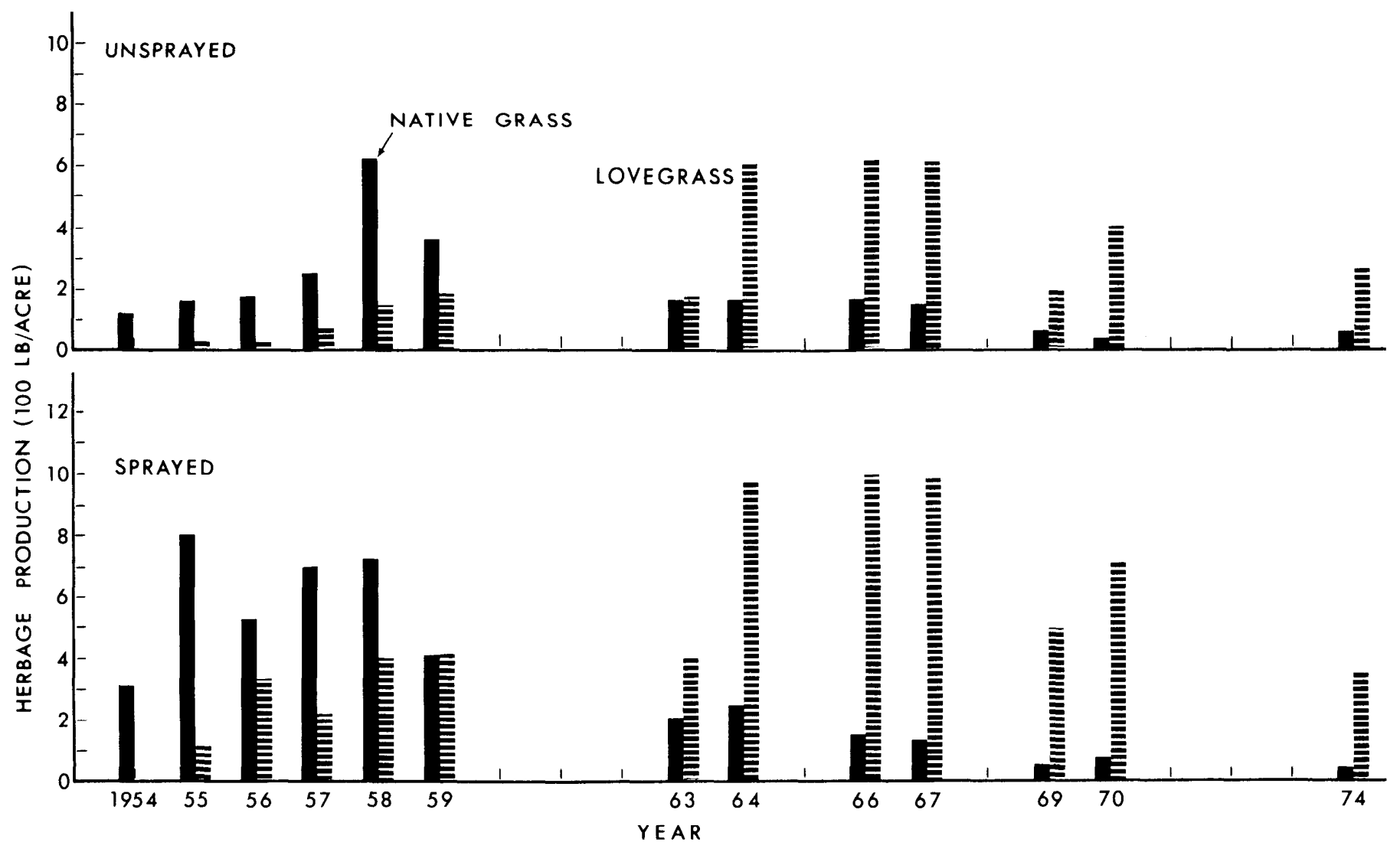

Fig. 3. Herbage production of native perennial grasses (solid bar) and Lehmann lovegrass (hatched bar) on sprayed and unsprayed areas.

product of current August rainfall times previous-year JuneSeptember rainfall. During the first 5 years, when native grass production averaged $611 \mathrm{lb} / \mathrm{acre}$, these two variables accounted for $93 \%$ of the year-to-year variability in production. The sixth year (1959) was not included in the initial period because lovegrass competition had begun to affect the production-rainfall relationship seriously by that time.

After 1959, when summer rainfall was lower and lovegrass competition more severe, native grass production on the sprayed area did not respond to changes in rainfall, but instead decreased about $25 \mathrm{lb} /$ acre per year due to lovegrass competition. These relationships are in marked contrast to the strong, highly significant correlation between summer rainfall and native perennial grass production on adjacent native ranges (Cable, 1975).

On the unsprayed area, native grass production increased with time during the first 5 years, but more gradually than on the sprayed area because of the restraining influence of mesquite competition. Production averaged $267 \mathrm{lb} / \mathrm{acre}$, less than half that on the sprayed area. Between 1959 and 1974, as on the sprayed area, native grass production decreased with time, in response to the combined competition from mesquite and lovegrass. The rate of loss averaged $20 \mathrm{lb} /$ acre per year. Production averaged $151 \mathrm{lb} /$ acre for the period, only slightly less than on the sprayed area.

\section{Lovegrass Production}

The first 6 years was a period of stand establishment and increasing production. Although the increases on the unsprayed area were only about half as rapid as on the sprayed area, changes in lovegrass production on both areas were associated primarily with the passage of time, rather than with changes in rainfall. Production increased $82 \mathrm{lb} /$ acre per year on the sprayed area and $40 \mathrm{lb} /$ acre per year on the unsprayed. For the first 6 years lovegrass production averaged $251 \mathrm{lb} /$ acre on the sprayed area and $74 \mathrm{lb} /$ acre on the unsprayed.

Lovegrass apparently reached optimum productivity for the site by 1959; thereafter production varied primarily with changes in rainfall. Between 1963 and 1974, lovegrass production on both the sprayed and unsprayed areas was influenced about equally by: (1) the product of current June-August rainfall times previous June-September rainfall, and (2) previous September-May rainfall. Unlike native grasses, which do not respond to winter precipitation, lovegrass responded to winter moisture because it remains much greener during the winter and produces much more spring herbage than the natives. The combined effect of these two rainfall variables accounted for $81 \%$ and $73 \%$, respectively, of the changes in lovegrass production on the sprayed and unsprayed areas between 1963 and 1975. Mesquite competition during this period held lovegrass production on the unsprayed area to about $60 \%(478 \mathrm{lb} /$ acre $)$ of that on the sprayed area (819 $\mathrm{lb} / \mathrm{acre}$ ).

\section{Economic Considerations}

The sprayed area consistently produced more grass herbage than the unsprayed area, particularly during the first 4 years. This increased grass production more than paid the cost of the treatments within the first 4 years (Cable and Tschirley, 1961). These increases in grass production are reflected in the stocking records for the pasture, which show average stocking for 1943-53, before the study started, of 2.11 head $(10.2$ head/section yearlong), compared to 4.33 head (21.0 head/ section) for the study period, 1954-74. There are two points 
to remember, however. First, since the early years were unusually wet, we cannot always expect results as favorable as these. Sccond, treatment costs have risen considerably since 1954 , so that a longer period of increased production would be required for similar treatments to pay off now.

\section{Discussion}

It is apparent from Figure 2 and the rainfall-production relationships discussed above that: (1) lovegrass establishment during the first 6 years was assisted by the high summer rainfall, (2) the large increases in lovegrass production in the middle years were promoted by the high levels of winter precipitation during those years, and (3) the reduced lovegrass production during the 1969-74 period was associated with the reduced levels of both summer and winter precipitation. In contrast, native grasses were assisted by high summer rainfall in the early years; but for the remainder of the study period, rainfall was relatively unfavorable for native grass production.

Lovegrass herbage currently constitutes about $90 \%$ of total perennial grass production on the sprayed area and $80 \%$ on the unsprayed. Yields of native grass decreased $90 \%$ between the first 3 measurements (1954-56) and the last 3 measurements (1969-74) on the sprayed area and $63 \%$ on the unsprayed. Selective heavy grazing of the native grasses probably contributed to their decrease after 1960. Average utilization of all perennial grasses was $50 \%$ between 1961 and 1970 , but use of natives averaged $62 \%$, compared to $42 \%$ for lovegrass. However, since similar losses of native grass on areas seeded to lovegrass have been reported even on ungrazed areas (Cable, 1971), the decline in native grasses is atrributed mainly to the competition from lovegrass.

Large losses of native grass on areas seeded to lovegrass are common. However, the ability of Lehmann lovegrass to predominate over native grasses is closely tied to adequacy of rainfall. For example, on the Santa Rita at elevations below 3,400 feet and about 13 inches annual rainfall, Lehmann lovegrass is much less productive, coexists with native grasses, and does not compete with mesquite nearly as well as where rainfall is higher.

The change in grass composition to a predominance of lovegrass should not pose any serious management problems. Although lovegrass is not as palatable as native grasses during the summer growing season, in the winter it remains greener, is grazed more readily, and is higher in protein content than the major native grasses.

The rapid recovery of native grasses following the mesquite spraying indicates that seeding was not necessary, and costs would have been lower if lovegrass had not been seeded. Obviously, a need for seeding should be established before incurring such an expense.

A final question to be answered is: Would it be more profitable to respray this same area now, after 20 years, or treat a new area? Since, current production on the sprayed area is still higher than on similar untreated range, and since per-acre costs of aerial spraying are the same for initial treatment as for retreatment, higher returns could be obtained by treating a new area.

\section{Conclusions}

This 21-year study indicates: (1) the kinds of changes in grass herbage production that result from mesquite control and seeding to Lehmann lovegrass, and (2) that the benefits of treatment last at least 20 ycars on arcas where lovegrass is well adapted. The major conclusions are:

1. Perennial grass herbage production can increase dramatically following control of velvet mesquite, particularly if precipitation is above the long-time mean.

2. Treated areas need not be reseeded if a remnant stand of native grasses is present. A relatively sparse remnant stand can quickly reoccupy the site under favorable conditions.

3. Lehmann lovegrass can rapidly (within 2 years) occupy a mesquite-controlled area, and over a period of years will become established within an existing stand of mesquite.

4. Native perennial grasses are not as competitive as Lehmann lovegrass. Over a period of years lovegrass competition will reduce the natives to from 10 to $20 \%$ of the grass stand.

5. Lehmann lovegrass production responds about equally to winter and summer rainfall.

6. Spraying velvet mesquite with $2,4,5-\mathrm{T}$ in two successive years can provide long-lasting benefits. After 20 years, the sprayed area in this study was still producing significantly more grass than the unsprayed area.

7. It would be more profitable, if treatment costs are the same, to control mesquite on a similar undisturbed area than to retreat this area, after 20 years.

\section{Literature Cited}

Cable, Dwight R., and Fred H. Tschirley. 1961. Responses of native and introduced grasses following aerial spraying of velvet mesquite in southern Arizona. J. Range Manage. 14:155-159.

Cable, Dwight R. 1971. Lehmann lovegrass on the Santa Rita Experimental Range, 1937-1968. J. Range Manage. 24:17-21.

Cable, Dwight R. 1975. Influence of precipitation on perennial grass production in the semidesert southwest. Ecology 56:981-986.

\section{Moving? Be sure to send your change of address to the Denver Office at 2120 So. Birch St., Denver, Colo. 8D222.}

